
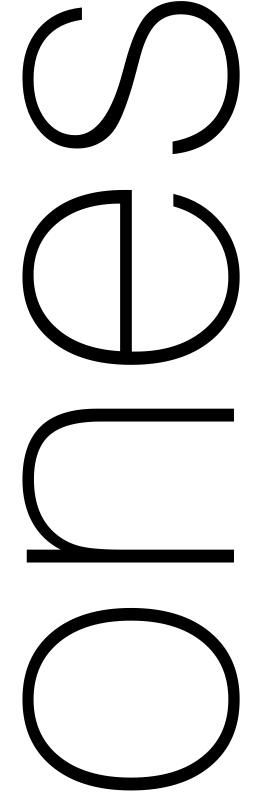

- proyecciones
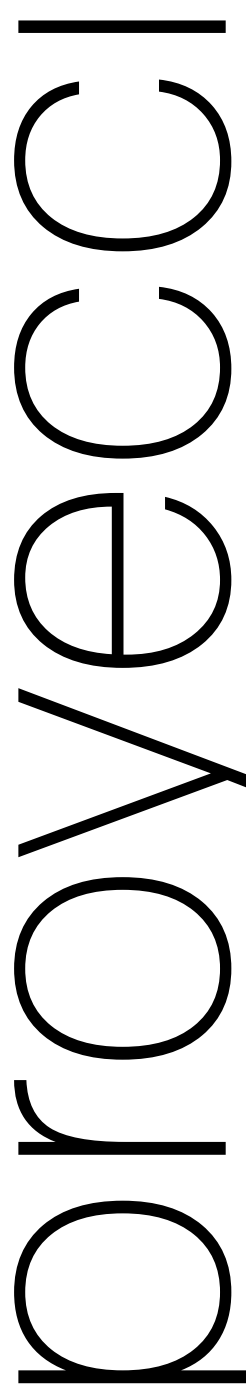


\section{- Ciclo «La mejor película es...»}

En 2016 el Taller de Cine UNL organizó un ciclo de proyecciones llamado «La mejor película es...», cuyo texto de presentación era el siguiente: "La idea se presentaba novedosa, prometedora: convocar a directores y críticos de cine de la ciudad para que cada uno eligiese una película y se encargara de presentarla al público haciendo conocer el por qué de su elección. El resultado fue tan estimulante y novedoso como la idea original. Se completó una lista de películas muy variadas, más de lo que la decisión de un grupo más restringido de personas hubiese logrado. La cuestión de la edad de los electores no siempre se refleja en la elección de películas si nos guiamos por el criterio de «clásicas» y «actuales», o, entre las «más nuevas» o «más antiguas». Se da el caso de un joven director que elige una película de Bergman, por ejemplo, pero es cierto también que las películas más recientes fueron elegidas por los directores más jóvenes. A su vez queda insinuada una pregunta o posible tema de discusión que quizás hasta llegue a surgir en algunas de las presentaciones de las películas: El cine ¿ha ido perdiendo en los últimos años, o décadas, el nivel de calidad que había alcanzado en su momento a partir de los films de un Bergman, de un Resnais, o de un Huston?, o planteándolo de otro modo: ¿es más problemático hoy, armar un programa de calidad, teniendo que elegir entre las producciones más recientes, que hace algunos años, cuando la elección se hacía entre los films de los directores ya citados, y otros 
como Visconti, Hitchcock, Antonioni, Ray, Welles, etc? En cualquiera de los casos, bienvenida la variedad y la diferencia.»

El desarrollo del Ciclo fue el siguiente: Patricio Coll presentó Hiroshima mon amour de Alain Resnais, Patricio Agusti presentó Winter Sleep (Sueño de invierno), de Nuri Bilge Ceylan, Arturo Castro Godoy presentó ¿Dónde está la casa de mi amigo? de Abbas Kiarostami, Marilyn Contardi La costilla de Adán, de George Cukor, Roberto Maurer Siempre hay un día feliz, de Stanley Donen y Gene Kelly, Julio Hiver presentó El estrangulador de Boston, de Richard Fleischer, Agustín Falco presentó Un verano con Mónica, de Ingmar Bergman, Mario Cuello Chantrapas de Otar losseliani, Oscar Meyer Mi noche con Maud de Eric Rohmer, Diego Soffici In the Mood for Love (Deseando amar) de Wong Kar Wai, Raúl Beceyro Fat city (Ciudad dorada) de John Huston, y para terminar el ciclo Marilyn Contardi presentó Los 400 golpes, de François Truffaut.

En cierto momento, Patricio Agusti nos envió un mail donde emitía algunas reservas sobre el ciclo: «Estimado colega Raúl, acabo de leer tu último posteo sobre el ciclo de cine al que participé y me preguntaba acerca de su texto. ¿Por qué ese nivel de preguntas tendenciosas y sesgadas sobre el cine? ¿Por qué arranca la pregunta con el calificativo «perdiendo» nivel de calidad, como si esperara una contestación favorable a sus expectativas sobre el pasado y presente del cine... de hecho reniego a la consigna de «mejor película es» que entiendo intenta tener un gancho publicitario de convocatoria (al cual accedí sabiendo de las buenas intenciones de su organización), pero ahora esto de seguir alimentando estas construcciones arbitrarias sobre la historia del cine. ¿Se puede comparar acaso un artista o una época sobre otra sin caer en reduccionismos? ¿Se gana algo más que alimentar la división y el prejuicio con este tipo de preguntas del estilo «todo tiempo pasado fue mejor»? Deseo que el ciclo UNL sirva para poder seguir apreciando las joyas invaluables que dio nuestro cine en el pasado pero también para poder descubrir con ansias el nuevo cine que se avecina, te mando un abrazo grande y aprovecho a saludarte por el día del documentalista. Patricio.»

Para concluir la incipiente polémica, Marilyn Contardi escribió la siguiente aclaración: «En el texto de presentación del Ciclo de Cine 2016 incluí unas preguntas para redondear y rematar el texto. No tuvieron otro propósito, no tuve ninguna intención de iniciar un contrapunto o discusión entre cine del «pasado» y cine actual. Todo el cine es actual, el de Chaplin, el de Ozu, el de S. Ray, el de Cassavetes, tanto como el de Kiarostami, el de Matías Piñeyro o el de Cristi Puiu. Me despido con esta reflexión de Jean Renoir: «El tema no tiene demasiada importancia (...) La originalidad está en la forma, no en el fondo (...) Es un error darle tanta importancia a la historia, a la anécdota...» iHasta la vista, o mejor, hasta el miércoles para ver: Un 


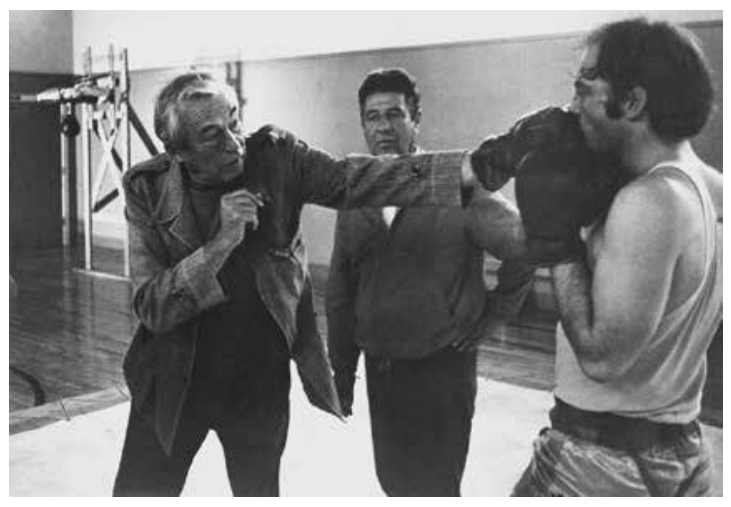

RAÚL BECEYRO: Para comenzar este ciclo elegí Fat city (Ciudad dorada) de John Huston. Hubiera podido elegir otras películas, hubiera podido elegir esa película que, para François Truffaut ha despertado mayor cantidad de vocaciones de cineastas, que es EI ciudadano de Orson Welles. Pero tengo la impresión de que Fat city tiene una característica que la hace muy útil en un ámbito como el Taller de Cine de la UNL o en general, todo lugar donde se enseña a hacer cine: Fat city es una lección de cine. No es que hable sobre el cine o que muestre una filmación: van a ver una película normal que cuenta la historia de dos boxeadores. Pero si uno mira con atención los 6 ó 7 minutos iniciales de la película uno puede ver cómo Huston enfrenta y resuelve (de la manera en que puede hacerlo un cineasta excepcional como es John Huston), todos los problemas que un cineasta enfrenta en el momento de la filmación e incluso en el momento del montaje.

Voy a contarles los primeros minutos de la película que van a ver. Comienza con unas tomas documen- tales, y hablo de documental no para caracterizar un "cine documental» que se diferenciaría de otro tipo de cine, que sería «de ficción». Cine, como madre, hay una sola, y el documental es simplemente el cine manejando materiales que pertenecen al orden de lo real y que deben ser enfrentados por el cine de una manera particular.

Estas tomas documentales tienen dos características que indican ese material real. Vemos situaciones, lugares, personas de la ciudad de Stockton (hay un cartel que lo indica) y, en todos los casos, sin sonido directo, el sonido que corresponde a eso que estamos viendo: hay gente que habla con otra gente y no se escucha lo que dicen. Eso señala la procedencia de esos materiales: el documental puede tener la imagen de algo real, pero muchas veces es muy diff́cil tener el sonido.

Las imágenes documentales, esos fragmentos de lo real que están en un film simplemente yuxtapuestos, sin relación unos con otros (el montaje es discontinuo en los documentales, salvo los grandes documentales, que logran construir un montaje continuo), pegados simplemente uno junto a otro, pero a Huston esta áspera superficie de lo real no le gusta, y entonces ¿qué hace para suavizar ese paso de una toma a otra? Simplemente las une en una sobreimpresión, superponiendo el final de una toma con el comienzo de la otra, como una manera de suavizar ese paso.

Después de estas tomas documentales de introducción vamos a una habitación del hotel, donde está el héroe de la película, y mirando con atención, veremos cómo Huston va tomando las decisiones que toman todos los cineastas cuando filman. La primera de esas decisiones es dónde poner la cámara. Es- 
tamos en un cuartucho de hotel y la cámara se coloca en el único lugar donde puede: en un rincón. La segunda decisión es a qué altura poner la cámara. Huston tiene el problema de que el personaje está acostado, se para, camina, se sienta en una silla, etc. Puede elegir todas las alturas posibles, desde la cual verá bien al personaje en cierto momento, y mal en otros. En el Capítulo 35 de su libro de memorias A libro abierto [Puede leerse el Capítulo 35 de John Huston, en el $N^{\circ} 10$ de estos Cuadernos de Cine Documental], Huston dice que la cámara puede estar "sentada o parada", es decir la altura adecuada para ver bien a alguien que está sentado o parado. Huston elige en el cuarto de hotel una altura intermedia, pero usa algún procedimiento (contraluz con lo cual solo se ve la silueta del rostro del personaje cuando se acerca a cámara, mirar sus manos en otro momento en que se aproxima), para disimular los momentos en que no tiene la «buena altura».

Luego está la elección del plano (resultado del objetivo utilizado y la distancia real de la cámara al personaje) y luego está el espacio. Vamos a ver las cuatro paredes, el piso y el techo de ese miserable cuarto de hotel. Huston construye así el espacio, que no viene dado, no es el espacio de la realidad, es el espacio del cine. Y luego salimos del cuarto, y nuestro personaje va caminando por los pasillos hasta la puerta del hotel. ¿Y cómo hace Huston? Muestra cada uno de los metros reales, de los pasos reales que el personaje da. El personaje recorre la distancia real, en el tiempo real. No es lo que hace el cine en la mayoría de los casos. En general el cine elimina tiempos y espacios «innecesarios». Si se filmara la llegada de algunos de ustedes a esta sala, seguramente la Toma 1 se haría en el frente del edificio y la Toma 2 entrando en esta sala. Seguramente se hubiese eliminado el recorrido por el pasillo hasta llegar acá. Por su parte el espectador ya ha sido educado por el cine y asocia sin problemas el exterior del edificio y la entrada a esta sala. Pero acá Huston no elimina un metro, asimilando el espacio y el tiempo de la realidad, al del film. Una vez llegado a la puerta del hotel el personaje decide volver al cuarto, a buscar el bolsito, y no es que vuelve a recorrer de vuelta todo ese espacio que recorrió de ida. Como en el cine, hay un corte y se va a un rincón del cuarto, el personaje toma el bolsito y sale de cuadro. Huston tiene principios pero no es principista. Ya ha construido este espacio y no tiene por qué hacerlo de nuevo.

La secuencia siguiente ocurre en el gimnasio. Y si hasta acá podíamos ver una especie de inventario de los problemas que se plantean en filmación, en el gimnasio se plantean todos los problemas que se plantean en el montaje.

Huston tiene, en el gimnasio, a dos personas que se encuentran, hablan y pelean. ¿Cómo filma y cómo monta esta secuencia? Como se hace en la mayoría de las películas cuando se filma una conversación de dos personas, con tomas correspondientes o simétricas, con una persona de frente, digamos, cuando esa persona habla, y de espaldas, cuando escucha. ¿Por qué se filma así? Porque de esa manera cada personaje, de frente o de espaldas, ocupa el mismo lugar en el cuadro, a la derecha o a la izquierda.

El problema de este tipo de situación es que no hay "que saltar el eje», es decir pasar del otro lado de la línea que une a los dos personajes, porque si no, se invertiría la posición en el cuadro.

El gran problema de la secuencia del gimnasio es que Huston filma a dos boxeadores que pelean, $y$ 


\section{Presentación de Hiroshima mon amour, de Alain Resnais, a cargo de Patricio Coll}

son ellos los que "saltan el eje», así que hay que estar atento a los movimientos de los boxeadores para poder montar sin problemas. Huston nos enseña, en una situación peligrosa, cómo debemos filmar, para poder montar.

En los 6 ó 7 primeros minutos de Fat city entonces, tenemos una lección de cómo debemos filmar, y cómo tenemos que montar.

No resulta raro que sea John Huston quien nos enseñe esto, porque en el Capítulo 35 de su libro $A$ libro abierto, tenemos una especie de lección de cine escrita sobre cómo filmar: por dónde tenemos que empezar a filmar, cual puede ser la altura de la cámara, el plano secuencia, etc.

Termino justamente con el plano secuencia del hotel: toda la secuencia del cuarto está resuelta en un solo plano. ¿Y por qué? Cuando hay tiempo (tenemos a alguien que está ahí, dejando pasar el tiempo) hay que usar el plano secuencia, no se puede cortar y pasar a otra toma, porque en el plano secuencia hay una acumulación temporal, así que la mejor manera de filmar a alguien que está en su cuarto de hotel sin saber qué hacer, viendo pasar el tiempo, es preservar el tiempo real, no cortar, usar el plano secuencia. De esa manera el tiempo se va acumulando: Andrei Tarkovski hablaba de la «presión temporal» que se acumula en el plano secuencia.

Les pido una cosa: durante los primeros minutos de Fat city traten de recordar algunas de las cosas que les acabo de decir. Después pueden verla como se ven todas las películas, para así poder llegar al final, que es uno de los más grande finales de la historia del cine.

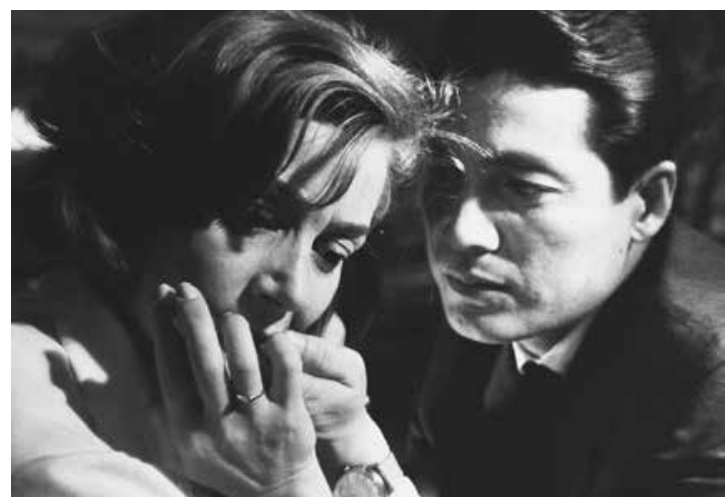

PATRICIO COLL: Es riesgoso lo de elegir «La mejor película...» pero lo intentaremos. Como todos saben Alain Resnais nació en 1922 y murió en 2013. Tiene una obra amplísima, en muchos sentidos. Perteneció a la primera promoción de una famosa escuela de cine: el IDHEC, Instituto de Altos Estudios Cinematográficos, de Francia, que fue fundado en 1943. Se dice que no terminó la carrera, y que en el 46 empezó a trabajar profesionalmente como Montajista (ahora se dice Editor), porque al parecer el montaje era el aspecto del cine que más le interesaba. Pero desde muy temprano empezó a realizar cortometrajes, entre ellos Van Gogh, que le valió un Oscar en 1950.

Resnais perteneció a la Nueva Ola francesa, junto a Godard, Chabrol, Truffaut, aunque era mayor, y además no fue crítico en Cahiers du cinéma, como todos ellos. Como otros de esos cineastas (Agnès Varda, Chris Marker o Jacques Demy) se formó en la industria. A los 37 años debuta en el largometraje, con el film que veremos ahora, y que originariamente era un proyecto para un documental sobre la Bomba atómica. Pero 
Presentación de Winter Sleep (Sueño de invierno), de Nuri Bilge Ceylan, a cargo de Patricio Agusti

Resnais no quería repetir los procedimientos que había utilizado en la famosa Noche y niebla e incorporó al proyecto a Marguerite Duras, cuyo aporte fue importantísimo. En Cannes Hiroshima mon amour obtiene el Premio de la crítica, el mismo año que François Truffaut obtiene el premio al mejor director.

En esa época en que en Santa Fe se dio Hiroshima..., nosotros veíamos en los cines de Santa Fe Un condenado a muerte se escapa o El carterista, de Bresson, Patrulla infernal de Stanley Kubrick, El grito o La aventura de Antonioni, La fuente de la doncella de Bergman: una lluvia de gigantescas películas. Todas estas películas se veían en los numerosos cines que había en Santa $\mathrm{Fe}$, o en alguno de los dos cineclubes que funcionaban entonces: Gente de Cine y Cine Club Santa Fe.

Cuando vi Hiroshima mon amour era un espectador común que ni se imaginaba que alguna vez iba a estudiar cine. Cuando la vi experimenté una especie de asombro, de sorpresa, de locura. Yo no sabía si eso era vanguardia, cine experimental u otra cosa, pero sentí la tremenda libertad expresiva de Resnais en el manejo de los instrumentos formales con los que construía su película. Estos elementos innovaban o renovaban el lenguaje fílmico, en la textura de las imágenes, en la complejidad de la organización de los tiempos pasado y presente, en lo imaginario de los personajes o lo poético del realizador. Todo era insólito y me producía una exaltación basada en la emoción poética que desbordaba la película y por eso Hiroshima mon amour, como se dice ahora «me rompió la cabeza» y me dejó «sin aliento». Hiroshima mon amour fue para mí una revelación: el cine podía ser otra cosa, eso que nunca había experimentado ante una película. Esa fue la razón por la cual quise hoy presentarla aquí.

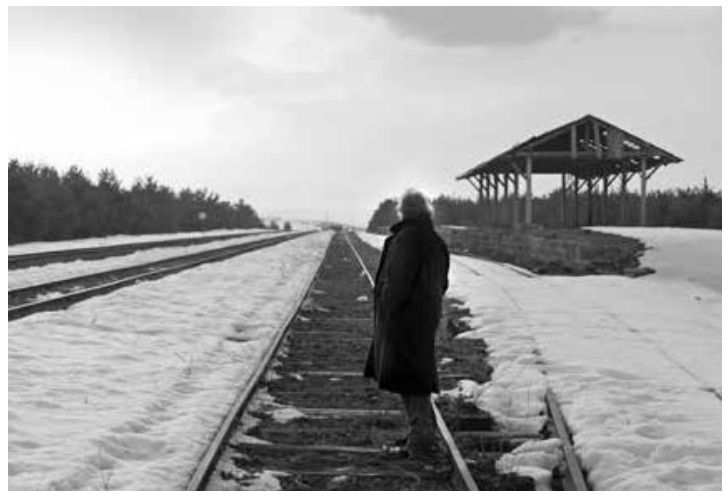

PATRICIO AGUSTI: Cuando se me propuso formar parte de este ciclo, eligiendo «la película que más te gusta», o «la que ha tenido mayor importancia en tu actividad de cineasta», temí caer en esas películas que todos conocemos, y que han sido vistas muchas veces. Quise rebelarme ante esa posibilidad y decidí elegir una película más de nuestro tiempo. Winter Sleep es una película de 2014 y tiene un parecido a los grandes cineastas, como Bresson, Kubrick, Tarkovski, aquellos cineastas que tienen un estilo definido y que rápidamente uno puede reconocerlos, que responden a los llamados de su tiempo en la búsqueda de una verdad, y eso es lo que los hace reconocibles, e irrepetibles. Quizá Nuri Bilge Ceylan sea un hermano menor de estos grandes nombres, pero cuando me encontré con su film, me pareció que iba por ese camino, sobre todo por dos cuestiones. En primer lugar porque el film plantea los conflictos de las relaciones humanas, tal como se plantean en nuestro tiempo. Los hechos suceden en una lejana Turquía, pero cuando terminé de ver esta película, se me plantea- 


\section{Presentación de ¿Dónde está la casa de mi amigo? de Abbas Kiarostami, a cargo de Arturo Castro Godoy}

ron muchos interrogantes sobre la moral, sobre las relaciones humanas, preguntas que nos podemos hacer tanto como seres humanos, como argentinos, en la situación que estamos atravesando actualmente. Por otro lado algo que llamó mucho mi atención, que me hizo disfrutarla, y por eso la traigo hoy acá, es su lado poético, ese dejar el tiempo necesario al desarrollo de las situaciones, y por eso los personajes son mostrados con la dignidad y la entereza, que es lo que distingue a las grandes películas.

Tarkovski decía que el uso del tiempo en el cine, es como la utilización perfecta de las palabras en literatura. Ahí se ve a un gran director, el que nunca utiliza golpes bajos, ni golpes de efecto.

En ese manejo del tiempo, tanto en lo que se refiere al juego actoral, como al manejo de las formas, está la mirada de cada cineasta, eso que diferencia a un director de otro.

Creo además que Winter Sleep es una película que invita a que la vean como un paisaje, y así los espectadores somos integrados al propio film.

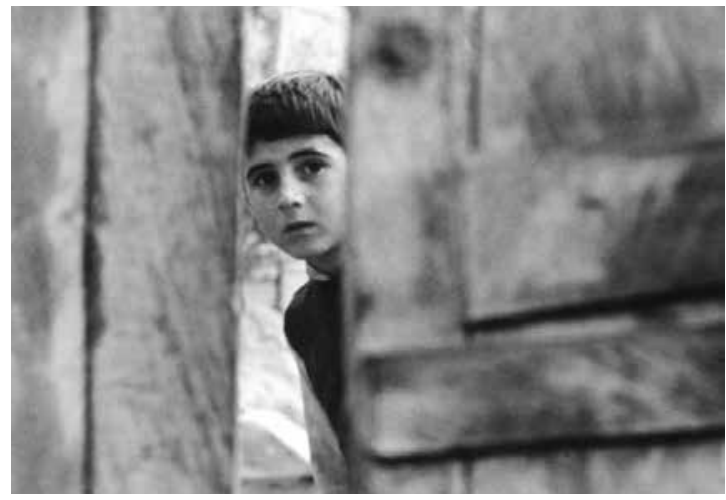

ARTURO CASTRO GODOY: La película que he elegido lo ha sido porque entendí que lo que se me pedía era que eligiera un film que tuviera una significación especial para mí en tanto cineasta.

En primer lugar ¿Dónde está la casa de mi amigo? es una de las mejores películas que vi en mi vida. Además me permitió ver claramente cuál es la jerarquía de los elementos cinematográficos en las películas que yo veía, y eventualmente en las películas que podría llegar a hacer.

La trama de ¿Dónde está la casa de mi amigo? es muy simple, con muy pocos elementos, con una gran economía, tanto en lo que concierne a la trama, como a las decisiones estéticas que materializan esa trama en el relato audiovisual: tiene una fotografía impresionante, la puesta de cámara no desborda creatividad, los personajes no tienen características muy específicas, salvo quizá por lo lejana que es para nosotros la cultura iraní. Pero hay en este film algo fundamental a la hora de hacer cine: la decisión consciente de, simplemente, contar una historia. Esto es 
Presentación de La costilla de Adán, de George Cukor, a cargo de Marilyn Contardi

lo esencial, $\mathrm{y}$ lo he aprendido con el tiempo en el quehacer audiovisual: contar una historia.

No importa con qué cámara filmás, si tu actor es mozo de un bar, lo único que importa es contar una historia, y así tener la posibilidad de mirar el mundo a través de los ojos de un realizador, que nos cuenta una historia que significa mucho para él, y que termina significando mucho para nosotros. Nosotros nos identificamos automáticamente con algunos de los personajes, y entonces recorremos la película con ellos, en su propia piel.

Viendo ¿Dónde está la casa de mi amigo? pensé: "con tan pocos elementos, sin buscar ninguna originalidad, el director logra encontrar muchas cosas, al simplificar, maravillosamente, todas las decisiones estilísticas de la película». Kiarostami deja que las imágenes y los sonidos nos cuenten una historia, que termina impactándonos, precisamente, por lo primario, lo básico, de los conflictos y los valores que se ponen en juego en la película.

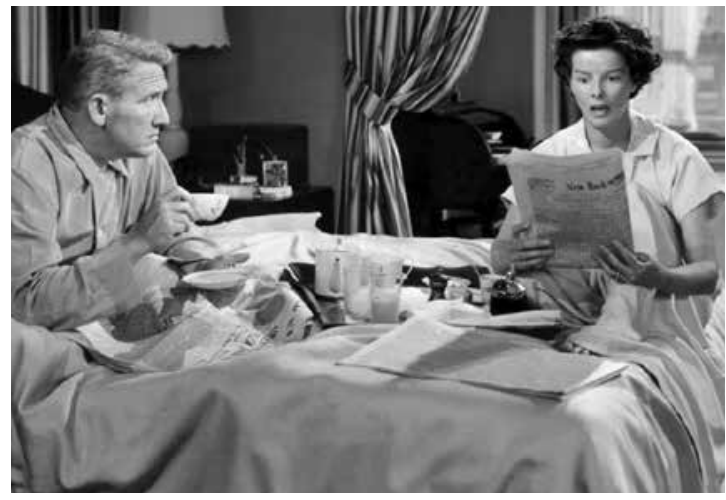

MARILYN CONTARDI: Hoy vamos a ver una hermosa película del período que llamamos clásico (evidentemente a Cukor no se le hubiera ocurrido llamar clásico al cine que estaba haciendo). Las categorías aplicadas a las distintas épocas del cine no son demasiadas, y en algunos casos, o mejor dicho, aplicadas a las mejores películas, orientan muy poco. La llegada del sonido al cine poco antes de la década del 30, introdujo un elemento capital, y el paso del mudo al sonoro significó un cambio en la manera de hacer cine. Sin embargo, para algunos críticos como Bazin, ese nuevo elemento no cambió fundamentalmente el modo de narrar en cine por lo menos para la corriente que él denomina realista - que está presente desde el comienzo mismo del cine-, y que es en verdad la corriente más interesante del cine, más bien «agregó» algo que ya de alguna manera, estaba presupuesto en los criterios de realización. Si aceptamos ese punto de vista, se relativizan bastante los cambios que fueron dándose en la manera de contar en el cine a lo largo de su historia. 
Pero volviendo al comienzo, el cine clásico abarcaría un período que llegaría hasta los años 50 y a partir de ahí entraríamos en lo que se puede llamar cine moderno. Como se ve más que de dos categorías podríamos hablar de dos grandes períodos.

Ahora bien, si la incorporación del sonido no produjo el quiebre tan grande, como señaló Bazin, en la manera de organizar las narraciones en el cine, fue imprescindible para el nacimiento y la consolidación de uno de los géneros con mayor éxito de público del cine americano: la comedia, también llamada comedia americana; la screwball comedy que algunos consideran un subgénero de la comedia, pero válgame dios, no entraremos en subgéneros aquí después de haberlos minimizado antes, además icon qué coraje seríamos capaces de enfrentar una inmanejable subcategoría como la de cine postmoderno?

La costilla de Adán (Adam's ribb), el film que vamos a ver, ha sido dirigida por Georges Cukor y pertenece al género comedia.

Las buenas películas de género lo transcienden, los mejores films de John Ford y de Alfred Hitchcock por ejemplo, trascienden los conocidos géneros del western y de los films de suspenso y valen por sí mismas; aunque hayan sido producidas y realizadas dentro de las líneas de producción de "géneros» de los grandes estudios, lo mismo que la película que vamos a ver.

En la época en que esta película fue realizada, en uno de los grandes estudios, la Metro Goldwyn Mayer aun cuando las campanas que anunciaban el final de la época se hubieran puesto ya a sonar muy por lo bajo- había departamentos donde se trabajaba para cada rubro de la producción de un film, y había uno, de gran relevancia: el Departamento de Guio- nes. Los guionistas de esta película: Ruth Gordon y Garson Kanin, pertenecían al grupo de especialistas, más o menos fijos según las temporadas, contratados por el estudio. Ruth Gordon fue también actriz, ganó el Oscar a la mejor actriz de reparto por su actuación en Rosemary's Baby de Roman Polanski y además de guionista, autora de obras de teatro. Por el guión de este film tanto ella como Garson Kanin, que era su marido en la vida real, fueron nominados al Oscar por el mejor guión, y se dice que muchas de las situaciones planteadas en los guiones, al menos en los actuados por Tracy-Hepburn, eran reflejo de las ocurridas en la vida en común de los guionistas.

Entre los guionistas de aquella época encontramos a escritoras como Dorothy Parker, y Lillian Hellmann, hasta un William Faulkner trabajó como guionista en Hollywood; aunque al parecer para él no fue una experiencia muy feliz.

Georges Cukor era un realizador que venía trabajando desde los años 30 , década en la que toma vuelo la comedia americana. En 1939 había sido llamado para dirigir Lo que el viento se llevó, pero tuvo problemas con la estrella del film, Clark Gable, o mejor, fue Gable el que promovió su reemplazo, y el productor David Selznick lo reemplazó por Víctor Fleming. Se dice que a Gable le molestaba la inclinación homosexual de Cukor.

Pero Cukor se repuso rápidamente del traspié y dirigió una comedia, interpretada por Katharine Hepburn, Cary Grant y James Stewart: The Philadelphia Story.

La costilla de Adán es de 1949, en ese momento George Cukor es un realizador consumado, con gran experiencia y en la plenitud de su capacidad expresiva, el guión es excelente y la pareja de intérpretes 


\section{Presentación de Siempre hay un día feliz, de Stanley Donen y Gene Kelly, a cargo de Roberto Maurer}

no puede ser mejor: Spencer Tracy, uno de los más grandes intérpretes que ha dado el cine, con una larga carrera en su haber, lo mismo que su compañera: Katharine Hepburn. Una de las rasgos de películas como ésta, es la claridad en la exposición de lo que cuentan. Podría decirse que por un lado la película tiene que tener una trama básica simple, pero al mismo tiempo que el interés por su desarrollo nunca debe decaer, con diálogos y situaciones ingeniosos, sin perder jamás el ritmo y con una actuación sin fallas. Como se ve bastante simple si se puede mantener todo al mismo tiempo y al mismo nivel.

Otros nombres de directores muy conocidos que han sobresalido en la realización de comedias son Ernst Lubitsch, Frank Capra, Preston Sturges, entre otros. Cukor tenía la reputación de ser un excelente director de actores, pero claro aquí trabaja además con actores sobresalientes, Spencer Tracy por ejemplo, capaz de imponerse por su sola presencia.

Estamos en 1949 y la comedia americana ya compite con otro tipo de cine: un año antes, en el 48 , se realizó Ladrones de bicicletas. El cine clásico, el cine de género o de los géneros, si seguimos con ese esquema, ya se enfrenta al cine moderno iy todavía no hemos llegado al cine militante de los setenta!

Pero el tiempo pasa, las aguas se aquietan, y hoy podemos ver los mejores films del período «clásico», libres ya de los prejuicios que arrastran consigo los «nuevos aires» de cada época - y que suelen interferir en nuestros juicios- como si se hubieran filmado ayer y dispuestos a enfrentar la comparación con cualquier film actual que se quiera elegir.

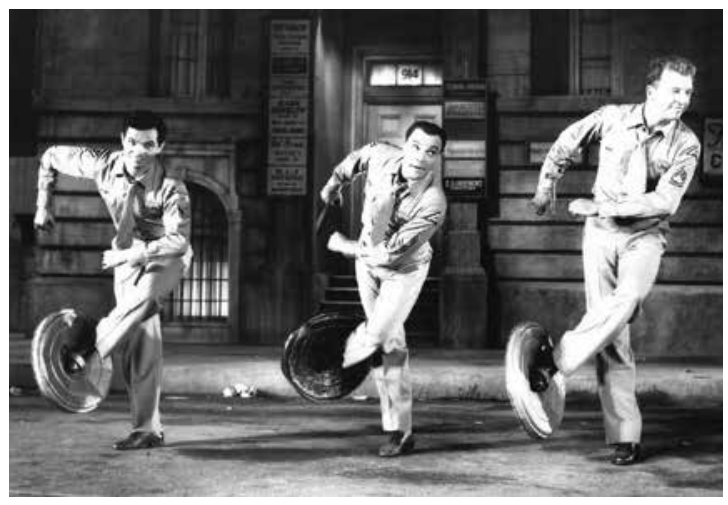

ROBERTO MAURER: Deseo aclarar de entrada que este ciclo de proyecciones me pareció algo poco transparente, desde el principio. ¿Uno elige la mejor película desde un punto de vista subjetivo, o debe hacerlo en nombre de la sociedad, eligiendo una obra maestra? Me parece que había, además, un golpe bajo, de tipo sentimental. ¿Qué película te gustó más o cuál cambió tu vida? No creo que ninguna película cambie la vida de nadie, y si a alguien le pasa eso, mejor que reflexione sobre su vida y sobre las películas. Es como decir: «ite acordás, querida, nos conocimos bailando esta canción?»

Como me di cuenta de que me estaban llevando a ese callejón, de alguna manera acepté tomar ese rumbo, y elegí bailar con el patito feo, que es la comedia musical. La comedia musical siempre fue un género menospreciado, y solo valorizado apelando a la nostalgia, pero en general era mal visto. Siempre fue acusado desde un punto de vista ideológi$\mathrm{co}$, al serle recriminado, con justicia, que Hollywood fabricaba deliberadamente productos escapistas. El 
colmo del escapismo era la comedia musical. Pero, también desde un punto de ideológico, recibió una ayuda, cuando se dijo que la comedia musical nos mostraba el potencial del ser humano: la felicidad es posible pero existe la injusticia social que le impide al ser humano desarrollarse.

Hubo un libro que en cierto momento era de lectura obligatoria, que es «Historia del cine» de Georges Sadoul. Sadoul era un dogmático del Realismo socialista, su posición era muy respetable, y prácticamente no menciona la comedia musical: habla de películas de ballet.

Había razones para que la comedia musical estuviera descalificada, porque las numerosas comedias musicales que se hicieron durante dos décadas eran, en su mayoría, mediocres. En general tenían un argumento muy débil, pensado solamente para introducir los números musicales, y lo que interesaba al público eran los cantantes, los bailarines. La mayoría de esas películas hoy en día casi no se pueden ver: podría hacerse una antología de los números musicales y ya está. Había un pasaje muy violento entre el realismo del cine, con su argumento, sus personajes, a una fantasía desbordante, cuyo extremo son los films de Busby Berkeley: esa transición no estaba resuelta. Hasta que apareció la Metro (el film que veremos hoy es de la Metro Goldwin Mayer). La ruptura se materializó con un ciclo de tres películas, que codirigieron Gene Kelly y Stanley Donen, sostenidos por el productor Arthur Freed, que antes de ser productor de la Metro, fue letrista de canciones. Freed logró convencer a Louis B. Mayer, el patrón de la Metro, a quien todos describen como una persona sumamente bruta, para que las produjeran.

Gene Kelly era un bailarín que había triunfado, y Stan- ley Donen era un bailarín que había fracasado, se conocían desde hacía muchos años, y se juntaron con este proyecto, con estas 3 películas: On the town (Un día en Nueva York) del 49, en el 52 el más conocido: Cantando bajo la lluvia y la tercera es la que vamos a ver ahora: Siempre hay un día feliz o Siempre hace buen tiempo.

El gran secreto, la clave de estos nuevos musicales, de esta nueva forma de encarar el musical, era incorporar esa fantasía cantada o bailada, a las peripecias del argumento. Gene Kelly era un prodigio relacionándose con el entorno que se le proponía: podía ser un niño, un objeto, un perro, y se relacionaba con gran espontaneidad con todo eso.

On the town se basaba en una comedia musical de gran éxito en Broadway, y para hacerla tuvieron que vencer la resistencia de Louis B.Mayer, que calificó a esa comedia musical de obscena y comunista, porque en cierto momento bailaba una mujer negra con un hombre blanco, en un baile amoroso. Lo fueron convenciendo y los actores eran, además de Gene Kelly, Frank Sinatra, Vera Ellen y otros. La historia mostraba a tres marineros bailando en las calles de Nueva York: tres marineros que tienen un día de franco en Nueva York, y conocen a tres chicas, y la pasan bien.

Después hicieron Cantando bajo la lluvia, otro hallazgo, la más famosa, y finalmente Siempre hay un día feliz, que veremos ahora.

La idea original era hacer una especie de continuación de On the town, pero luego la idea fue evolucionando. Después fueron a buscar a Sinatra, que al principio no fue bienvenido en la Metro, porque era considerado un tipo difícil, lo que era cierto. Además era posible también que Sinatra, que ya había ganado un Oscar, no quisiera ir a remolque de Gene Kelly. 
El otro bailarín de On the town había prácticamente desaparecido, así que dejó de pensarse en una especie de continuación de aquel film: eran tres marines que vuelven de la guerra.

¿Cuál es la particularidad de Siempre hay un día feliz, que la diferencia de lo que se había hecho en Hollywood en ese momento? Se dijo que era la primera comedia musical "cínica», ya que muestra a tres marines que vuelven a la vida civil, con sus proyectos y sus sueños, y que diez años después ninguno ha logrado concretar esos proyectos y esos sueños. Esa visión amarga de la posguerra era algo demasiado nuevo para una comedia musical. Hay además una crítica feroz a la televisión, en una época en que la televisión se convertía en la gran rival del cine, además de una burla a la publicidad.

Quizá por estas razones Siempre hay un día feliz no tuvo éxito. La crítica la recibió muy bien, pero dicen que la Metro no la apoyó, y el público no estaba preparado para la visión amarga de esta comedia musical.

Dice Andrew Sarris, un crítico muy respetado, que la idea del musical para la Metro nunca llegó a materializarse debidamente. Hay que reconocer que estas comedias musicales, por muy innovadoras que fueran, y ahora se las ve muy bien, tenían sus debilidades, incluso el inevitable final feliz.

Actuaron en Siempre hay un día feliz: Gene Kelly, Dan Dailey y Michael Kidd, gran bailarín y coreógrafo, además de Cyd Charisse, la chica con las piernas más largas de Hollywood, como vamos a ver ahora, en varios números musicales, algunos de ellos extraordinarios.

Después de esta película Gene Kelly y Stanley Donen se separaron y quedó trunca esta tentativa renovadora. Porque después vendría Amor sin barreras, pero esa es otra historia. Se cuenta que Kelly y Donen tuvieron muchas discusiones, y se cuenta una historia que tiene más que ver con las revistas de chismes que con el arte cinematográfico. Ambos estaban casados, con chicas que participaban en la película, y una de ellas había sido novia del otro, no recuerdo cual. Dicen que durante la filmación cada uno miraba a la mujer del otro y cuando murió Kelly, Stanley Donen habló de que habían vivido una especie de relación incestuosa. Incluso sucedió que años después uno de ellos se separó y se casó con la mujer del otro. [El crítico Roberto Maurer alude aquí al casamiento en 1960, de Gene Kelly con Jeanne Coyne, quien había sido la esposa de Stanley Donen.] 
Presentación de El estrangulador de Boston, de Richard Fleischer, a cargo de Julio Hiver

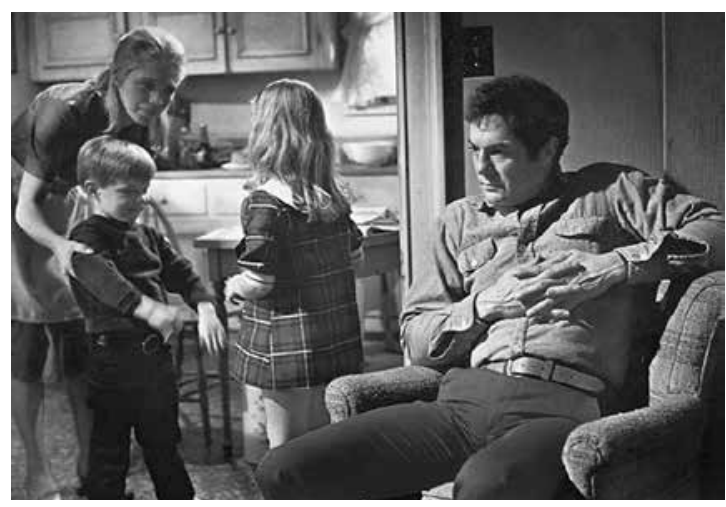

JULIO HIVER: Debo confesar que no sé si la película que elegí es «la mejor», pero es seguro que es una de las películas que, en mi juventud, me atrajo, me sorprendió. Recuerdo que a fines de la década del 60 había salido una serie de películas de gran presupuesto, con grandes figuras, como El affaire Thomas Crown, de Norman Jewinson, con Steve McQueen, Faye Dunaway, Alerta misiles, de Robert Aldrich, con Burt Lancaster y Richard Widmark, La amenaza de Andrómeda de Robert Wise, y El estrangulador de Boston, que veremos ahora.

Lo que tenían en común estas películas era la utilización de la pantalla partida, o pantalla dividida: se veían varias imágenes diferentes al mismo tiempo. Este es un procedimiento ya utilizado en el cine, pero nunca usado como elemento casi protagónico, y formando parte de la estética elegida por esos realizadores.

La pantalla dividida o partida, permite aquí ver una situación desde diferentes puntos de cámara, desde ángulos diferentes. A veces estas imágenes diferentes ocurren en el mismo instante, otras veces no. Es- to exige un mayor control de los movimientos de los personajes, y la filmación se hacía con varias cámaras. La filmación de cada toma era una gran puesta en escena.

En ese momento se hicieron varias películas, algunas muy taquilleras, con este procedimiento de la pantalla partida, y después se dejaron de hacer, no sé bien por qué. Hubo gente que criticaba este procedimiento diciendo que eso no era cine, que el cine era otra cosa.

El estrangulador de Boston fue dirigida por Richard Fleischer, e interpretada por Henry Fonda y Georges Kennedy, los policías encargados de atrapa al «estrangulador", y Tony Curtis, gran estrella en ese momento. El film está basado en un caso real y tiene dos partes bien diferenciadas. La primera es la búsqueda del asesino serial, y la segunda parte son los interrogatorios para confirmar que el sospechoso es el culpable. En esos interrogatorios se juega muy hábilmente con un espejo, que permite desplegar el punto de vista de la cámara. 
Presentación de Un verano con Mónica, de Ingmar Bergman, a cargo de Agustín Falco

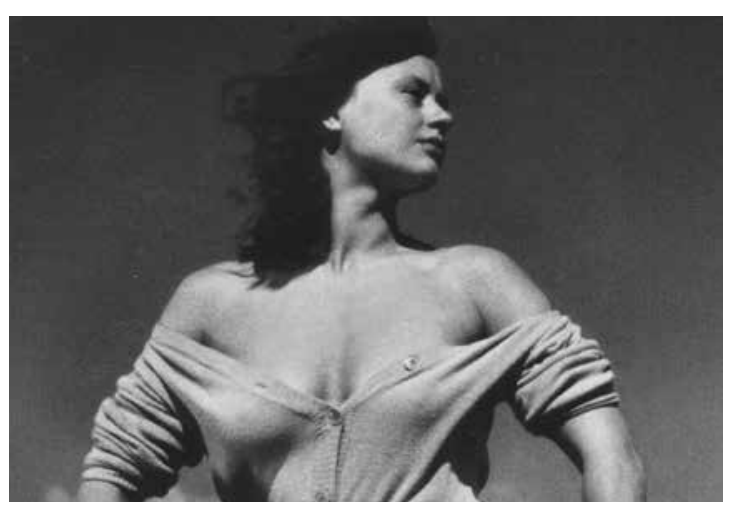

AGUSTín FALCO: Tomando el texto de presentación de este ciclo, donde se pregunta: «ies más problemático hoy, armar un programa de calidad, teniendo que elegir entre las producciones más recientes, que hace algunos años, cuando la elección se hacía entre los films de directores como Bergman, Resnais, Huston, Visconti, Hitchcock, Antonioni, Ray, Welles, etc?» desearía contestar por la afirmativa: sí, es más difícil. El cine vive hoy una crisis, pero si se lo toma en ese período que va del 50 en adelante, creo que el cine de calidad se arma a partir de excepciones. Si tomamos todas las películas hechas en el 54 ó 55, las películas de calidad son excepcionales. Creo que pasa lo mismo a lo largo de toda la historia del cine, con la excepción, quizá, de la década del 20, que es para mí la mejor época. Creo, entonces, que todo programa de calidad sigue siendo de excepciones, en donde hay que hurgar mucho.

Creo que lo que sucede en esa relación de autores que proponían un cine de calidad y el público, es que había un vínculo mayor. Eran grandes películas que eran vistas por mucha gente. Bergman era un cineasta que llenaba las salas argentinas.

Hoy los cines están vaciados hasta del cine convencional. Con los nuevos formatos, con la televisión, con el streaming, con las series, me parece que el folletín se fue a la televisión. Se hace difícil ver en el cine una buena película convencional, una película «bien hecha». El otro día vi la última de Spielberg, y, siendo completamente olvidable, me gustó: «está bien hecha». No pasa lo mismo con los «tanques», que no están bien hechos.

Uno podría esperar que el formato televisivo, que ahora está en las series, que era lo más parecido al folletín decimonónico, y que ahora se puede ver en el teléfono, o la compu, podría dejar para el cine la búsqueda de la profundidad, del tratamiento no convencional de los temas. Quizá eso pueda resurgir, pero por el momento se ve un vaciamiento del cine de todo tipo, tanto del de calidad como del cine convencional, tanto del moderno, como el clásico, como el alternativo. Las series quizá recuperan algo del clasicismo del cine.

Decía que armar un programa de calidad era más difícil, y eso por dos razones. En primer lugar una crisis de formatos, no de lenguaje, sino de soportes, de medios. Además no hay autores taquilleros, como podía serlo un autor como Hitchcock.

Es más difícil, pero es posible e incluso necesario. Ciclos como éste quizás ayuden. Cuando vi que algunos otros participantes habían elegido films de después del 2000, me pregunté si había elegido bien. Pero me di cuenta de que era algo distinto a elegir «la mejor película». Porque si no alguien hubiera elegido El ciudadano, o 2001, o algo así. Era más bien elegir la película que más me gusta. Y uno nunca sa- 


\section{Presentación de Chantrapas de Otar lo- sseliani, a cargo de Mario Cuello}

be por qué le gusta una película. A mí me emocionan las películas que me gustan.

Elegí Un verano con Mónica porque Bergman es uno de los directores que más me interesan. Y además la elegí porque no se ve mucho. Si uno va a un ciclo de Bergman, es raro que se incluya Un verano con Mónica. Incluso los que la vieron es posible que la hayan visto hace mucho, y no la hayan vuelto a ver. Este es un film de una etapa de transición de Bergman, más ligada a los Nuevos realismos, y diferente de la etapa «en color», a partir de Persona. Además hay en Bergman una relación entre el cine y el teatro que me entusiasma mucho; lo veo despreocupado por los límites de los diferentes lenguajes. Bergman hace "eso", que es una especie de mezcla entre cine y teatro, ya que es completamente cinematográfico y muy teatral al mismo tiempo, en lo mejor que tiene el teatro, que es el drama.

Bergman trabaja, como ningún otro director hombre, los mundos femeninos, y al mismo tiempo es una película muy masculina, y además trasciende lo femenino y lo masculino, porque es una película sobre el deseo, la angustia, la posibilidad o imposibilidad del amor, sobre los conflictos de la pareja. Está también la tensión entre la naturaleza (la isla, el mar) y lo ciudadano, la vida en la ciudad. Hay una mirada pesimista en esa búsqueda de lo natural, porque la vuelta a la ciudad es inevitable, y en ese sentido es trágica.

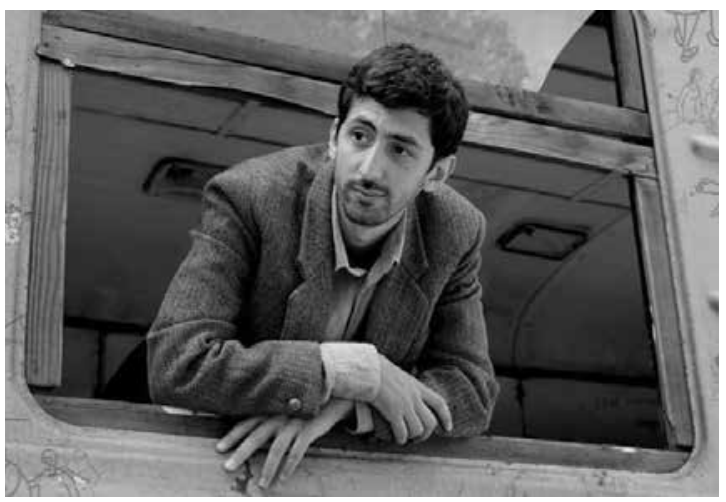

R. BECEYRO: Hoy pensábamos hablar de ese gran cineasta que es Otar losseliani, pero antes vamos a hablar de Miguel Mercuri. Anoche nos enteramos del fallecimiento de Miguel, y eso significó para los integrantes del Taller de Cine, una conmoción.

Durante varios años Miguel trabajó en el Taller e integró con otros alumnos un grupo que participó en la filmación de varias películas.

Los lugares en los cuales se enseña cine, no son buenos ni malos en sí, todos tienen cosas buenas y cosas malas. Pero lo que tienen de bueno las escuelas de cine es que posibilitan que un grupo de personas trabajen juntos. Pero además, en este caso, algunas de las virtudes de Miguel facilitaron la formación de ese grupo y el trabajo en común. Su virtud más evidente era la generosidad, la disponibilidad, y recordemos que vivía en San Cristóbal.

Esa disponibilidad se unía en su caso a algo fácil de decir, pero no tan fácil de practicar: su bondad. Miguel era un hombre bueno. Y esto, en una época en la que afloran las peores cosas en los individuos, es 
algo excepcional. Miguel era entonces un hombre excepcional.

La pérdida de un hombre bueno es una tragedia y la muerte de Miguel Mercuri es una tragedia para su familia y para sus amigos del Taller de Cine.

La mejor manera de homenajearlo es presentar una gran película de un gran cineasta.

MARIO CUELLO: Yo también vine al Taller de Cine y compartí con Miguel muchas aventuras. Pero quisiera recordarlo con una anécdota risueña. Hubo una época en que íbamos al BAFICl todos los años en una trafic de la Universidad. Ibamos como becarios, pero tanto Miguel como yo éramos ya mayores, habíamos llegado tarde al cine y teníamos más años que el becario promedio, estudiante de una escuela de cine. Recuerdo que una vez Quintín, entonces Director del BAFICI, se paró sorprendido ante estos dos becarios ya un poco viejos, y entonces le explicamos lo que era el Taller de Cine, y después nos reíamos mucho con Miguel.

Pero el espectáculo debe continuar.

Ahora veremos Chantrapas, de Otar losseliani, realizador georgiano radicado desde hace muchos años en Francia. Este es un film reciente de este director de 82 años, cineasta que conocí en el Taller de Cine, y del cual vi en el BAFICl la película que se conoció en Argentina como Hogar dulce hogar, película que me impactó. A partir de ahí empecé a ver films de losseliani: cortos y largos, documentales y ficciones. Me interesó mucho cómo filma, cómo utiliza el sonido. Recuerdo en su film La caza de las mariposas, la secuencia en que vemos a un cura llegar a una iglesia, en bicicleta, para tocar la campana. Pero previo al sonido del campanazo se escucha el ale- teo de una paloma. Todo ello, la llegada del cura, la paloma, la campana, tiene el sonido como cuestión fundamental.

Casi siempre los films de losseliani son películas corales, con muchos personajes, pero no es el caso de Chantrapas, en que seguimos a un solo personaje. Sus films cuentan historias que se cruzan, y suele usar actores no profesionales, ya que quiere evitar los tics de los actores de profesión.

Chantrapas es un film cuyo título toma una palabra rusa, de origen francés, «chantera pas», no cantarás, que era la nota que se le daba a quienes querían desarrollar el Bel canto, pero que los expertos consideraban que no tenían condiciones suficientes. Actualmente ese significado se ha extendido a quien se considera incapaz de hacer algo bien, un inútil podríamos decir.

El film cuenta la historia de un director de cine que, como el propio losseliani, intenta filmar en Georgia, cuando era una de las repúblicas socialistas soviéticas, quien se ve perseguido por la censura, que intenta modificar lo que quiere filmar. Como el propio Iosseliani abandona Georgia y se va a Francia, donde enfrenta otros, diferentes y al mismo tiempo parecidos, problemas. Vuelve a Georgia, mientras que losseliani sigue viviendo en Francia.

Chantrapas ha sido realizada por losseliani en 2010. 
Presentación de Mi noche con Maud de Eric Rohmer, a cargo de Oscar Meyer

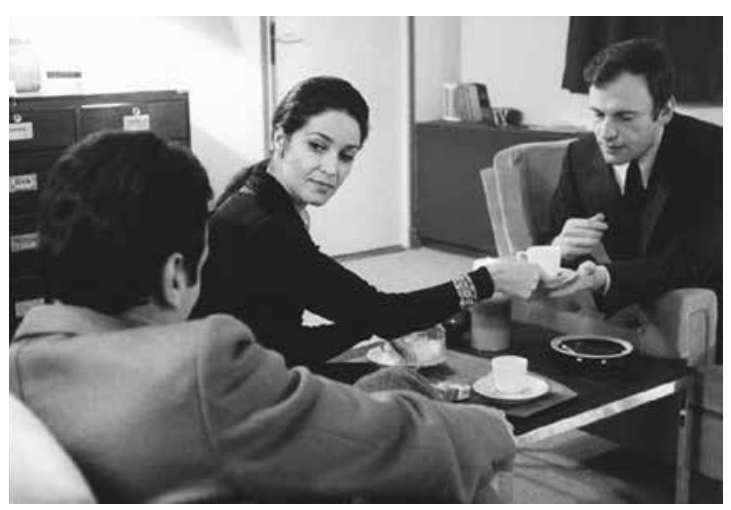

OSCAR MEYER: En primer lugar quiero agradecerles su presencia, y pedirles que me disculpen porque voy a hablar demasiado de mí a propósito de Mi noche con Maud, de Eric Rohmer.

Yo tenía 25 años cuando en 1970, no me acuerdo en qué cine ni con quien, fui al estreno en Santa Fe de Mi noche con Maud.

46 años después, me propusieron elegir una película y presentarla en este ciclo. La elección no era fácil: eran muchas las películas que con mérito suficiente revoloteaban en mi cabeza. Afortunadamente un encuentro casual con Jorge Colombo, a quien no veía desde hacía 30 años, vino en mi ayuda. Con Tobi, como lo llamamos los amigos, ingresamos en el Instituto de Cinematografía de la UNL en 1965. Recordando cosas ocurridas en aquellos años, había entre otras una que yo no recordaba para nada, pero que Tobi mantenía fresca en su memoria. Cito, aproximadamente, lo que me contó: «Te acordás que cada vez que venías a casa, sin ni siquiera saludar, pasabas como un balazo hacia el tocadiscos, y ponías el dis- co de Floreal Ruiz. Después de escucharlo un rato volvías y nos hablabas con entusiasmo de las maravillas de Mi noche con Maud». A la conjunción de la propuesta que me hicieron y el encuentro con Tobi, se debe que esté hoy aquí.

No es mi intención fundar mi juicio sobre la excelencia estética del film de Rohmer. Prefiero contarles las razones que hicieron de Mi noche con Maud el modelo ejemplar del cine que yo podía llegar a hacer en Santa Fe. Durante los años de mi relación con el viejo Instituto fui adquiriendo (en las clases, las conversacionesdiscusiones con otros alumnos, y en los films que vi en esa época, más de la mitad de las películas que visité en mi vida), un conjunto de ideas sobre el cine bastante desordenadas y dispersas. El film de Rohmer me ayudó a sistematizar algunas de ellas en un todo coherente, en lo que podría llamarse una poética cinematográfica. Entonces, concluía yo: debía seguir pensando en las ideas que quedaron en el tintero y hacer lo que hizo Rohmer en Mi noche con Maud.

1. Los personajes de Rohmer son burgueses, de una clase media intelectual, en una ciudad de provincia francesa: Clermont-Ferrand. Los de mi futuro film serían burgueses de una ciudad de provincia argentina: Santa Fe. En Clermont-Ferrand los burgueses de la clase media intelectual se conocen todos; los encuentros fortuitos se dan con frecuencia, los chismes son moneda corriente. Esta circunstancia condiciona sus relaciones y sus conductas. Lo mismo pasa en Santa Fe. Me inquietaba saber que Clermont Ferrand tenía un invierno crudo con mucha nieve. Me tranquilizaba diciéndome que en Santa Fe hace mucho calor en verano y tenemos ríos y lagunas. Solo bastaba usar con inteligencia estas contingencias temáticas y geográficas para salvar esos inconvenientes. 


\section{Presentación de In the Mood for Love}

(Deseando amar) de Wong Kar Wai, a cargo de Diego Soffici

2. Siguiendo el camino abierto por el Neorrealismo italiano Rohmer hacía un cine realista en el que los acontecimientos del relato se organizan siguiendo una lógica más laxa y polivalente que la de la causalidad rígida y lineal del cine clásico.

3. En Mi noche con Maud no hay racontos, ni vemos lo que imaginan o sueñan sus personajes. El corte seco en lugar del fundido o las sobreimpresiones, es el procedimiento utilizado por Rohmer para pasar de una secuencia a otra. Los conflictos, por más serios que sean, se expresan por medio de una gestualidad sobria y sin alzar la voz, y no con los excesos gestuales y sonoros propios de las sopranos en los momentos culminantes de las óperas dramáticas.

Todo esto que he venido diciendo lo encontraba hace 46 años, en Mi noche con Maud. Para terminar, no puedo dejar de mencionar el placer que me procuraba la manera en que el film muestra la relación entre elección y azar, entre el amor y la mentira, y la mentira del amor, el ambiguo final y, por qué no, la belleza de Maud, con su camiseta marinera.

Espero que, sin olvidar del todo mis palabras, no queden pegados a ellas, y puedan disfrutar del gran film de Rohmer.

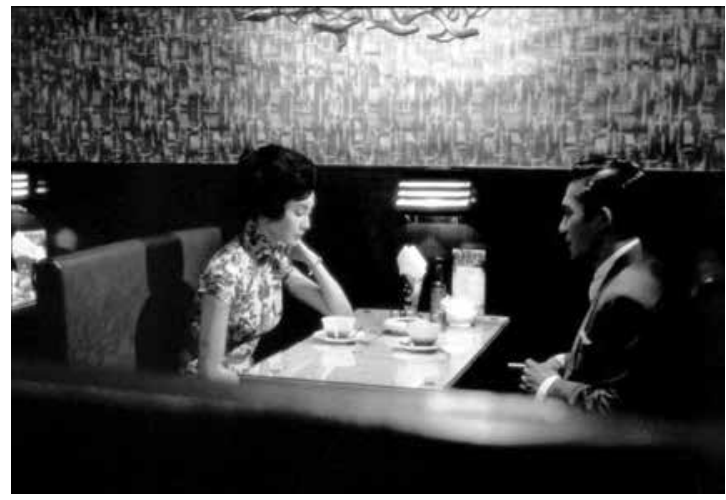

DIEGO SOFFICI: Vamos a ver una película de Wong Kar Wai, que de alguna manera inaugura el cine del Siglo XXI. Nacido en Shangai, a los 5 años su madre lo llevó a vivir junto a ella, en Hong Kong. Su madre era una adicta al cine y lo llevaba frecuentemente a ver películas, con la finalidad, además, de que aprendiera el nuevo idioma; él se crió hablando el mandarín y en Hong Kong, que era en ese momento una colonia británica, se hablaba el cantonés. Hizo estudios universitarios y se graduó de diseñador gráfico, además de realizar estudios de producción para televisión, trabajando en un canal de televisión de Hong Kong. Por su parte escribió guiones, pero hay que destacar que Wong Kar Wai nunca estudió cine. Realizó algunos de esos guiones que escribió y en cierto momento formó su propia productora.

Todos sus films los filmó en Hong Kong, excepto dos películas, una de las cuales la filmó, en 1997, aquí en Argentina: Felices juntos (Happy together). La otra la filmó en Nueva York: El sabor de la noche, interpretada por Norah Jones, quien debutaba entonces 
en el cine, y además compuso la banda sonora. Además actuaban Natalie Portman y Jude Law, y fue la única película de Wong Kar Wai hablada en inglés.

Elegí In the Mood for Love (Deseando amar) porque es su película que me gusta más, y porque presenta un notable trabajo estético.

La historia es muy simple: un hombre y una mujer que no se conocen, se van a vivir a una especie de pensión, y viven en cuartos contiguos. Estamos en Hong Kong en 1962, y los dos protagonistas se cruzan, en esos espacios comunes, se encuentran y descubren que sus parejas (la mujer vivía con un empresario que viajaba frecuentemente, la mujer del hombre también viajaba pero no se sabía qué era lo que hacía) les son infieles, y que tienen relaciones entre sí. Ellos tratan de saber el por qué de esas infidelidades, y poco a poco se dan cuenta de que se están enamorando. Tratan de evitar caer, ellos, en la misma infidelidad de sus parejas, y Wong Kar Wai trabaja muy sutilmente en el plano de las relaciones humanas.

Lo que más me maravilla es el trabajo estético del realizador. Es cierto que contó con la colaboración del gran fotógrafo Christopher Doyle, como en varios de sus films, y con la participación de actores que ya habían trabajado con él: Tony Chiu-Wai Leung, Maggie Cheung.

Hay algo sorprendente en esta película: Wong Kar Wai escribió muchos guiones en su vida, pero acá filmó sin tener ningún guión, lo que produjo demoras en la filmación, que se extendió durante 15 meses, y como se quedaron sin dinero debieron buscar otra productora. Una vez terminado el film lo presentaron en el Festival de Cannes, y ahí se produjo el reconocimiento mundial de Wong Kar Wai.
Cada encuadre está realizado con una precisión absoluta en su composición, y cada movimiento de cámara contribuye a esa armonía perfecta. Nunca cae en el Modelo de Representación Institucional, o, lo que es lo mismo, en un sistema convencional de cómo filmar una conversación, por ejemplo. No hay, en toda la película, ninguna situación filmada en planocontraplano, sino frontalmente, y utiliza mucho el montaje, fragmentando esa situación con planos de manos, de humo de cigarrillo, etc.

Además trabaja mucho el fuera de campo, eso que no estamos viendo en el plano. Tanto es así que prácticamente no vemos a las parejas de los protagonistas, ya que los vemos de espaldas, saliendo de cuadro, etc. Los escuchamos, pero no los vemos. De esta manera trabaja numerosas situaciones en el film. En cuanto al encuadre frecuentemente los protagonistas aparecen en un segundo plano, y adelante se ven otros objetos: paredes, ventanas, espejos, dando otro sentido al fuera de campo.

Wong Kar Wai trabaja mucho, además, la textura de la imagen, lo que también es mérito del Director de fotografía. La imagen es bastante contrastada, pero en relación directa con lo que se está contando. La ambientación es muy cuidadosa: no hay que olvidar que la acción sucede a principios de los 60 .

La música, un bolero cantado en español, acompaña en todo momento lo que les está pasando a los protagonistas, esa situación amorosa que están reprimiendo. Otros elementos son la lluvia, como signo de purificación, el reloj, ese tiempo que se prolonga gracias a algunas tomas en cámara lenta, como si Wong Kar Wai quisiera detener ese instante, para que perdure. Se trata, en suma, de lo que constituye el elemento central de lo cinematográfico, el manejo 


\section{Presentación de Los 400 golpes, de François Truffaut, a cargo de Marilyn Contardi}

del espacio y del tiempo. Estos mismos elementos serán retomados en una película que de alguna manera continúa a In the Mood for Love (Deseando amar), que se llama 2046, donde aparecen los mismos protagonistas, pero la atención se detiene en el pasado de todos ellos.

Por estas razones he elegido este film de Wong Kar Wai, que alguna vez fue definido como «el poeta de la imagen».

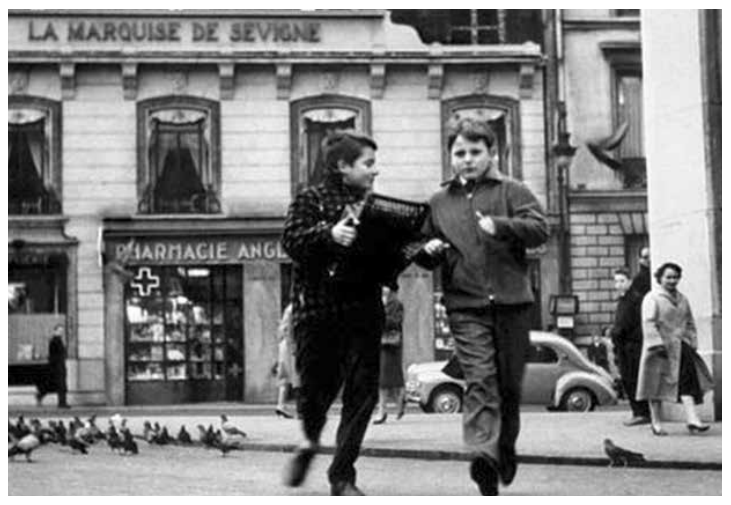

MARILYN CONTARDI: Acabo de asistir a la presentación del «Año Saer» en el Museo Rosa Galisteo, ahora nos encontramos en la sala Saer del Foro, y en este momento de la presentación del film de Truffaut, pienso en Saer y Truffaut como contemporáneos. La parte cinéfila de Juani, debe haberlo llevado a ver películas de Truffaut, que tenía algunos años más que él, pero no muchos, los dos nacieron en la década del 30. Compartieron el mismo «aire de la época», y cuando tenían 20 años, como ambos eran cinéfilos, pertenecieron a grupos de personas que debatían sobre cine, escribían sobre cine, hacían cine.

Hablando de este ciclo, recuerdo que cuando discutíamos sobre cómo materializarlo, o mejor qué nombre darle una de las opciones fue: «La película elegida es...», finalmente se optó por «La mejor película es...», en ese momento tal vez nos pareció que sonaba más «rotundo». De haber elegido la primera opción no habría habido necesidad de marcar algo que se escuchó varias veces: «no es la mejor película pero a mí me gustó por tal razón». Ahora, aquí soy yo quien la repite. 
Quiero decir además que la elección de la última película del ciclo había sido propuesta a un grupo de ex alumnas del taller. Por diversas circunstancias, en las que tal vez el «eterno femenino» —sí eso es algo más que un intríngulis- haya influído, la elección no se hizo. De ese modo la elección recayó en mí.

Los $\mathbf{4 0 0}$ golpes es el primer largometraje realizado por Francois Truffaut después de haber hecho 3 películas de corto y medio metraje, la más conocida de los cuales es Les mistons (Los mocosos). En esta ya había puesto a prueba o más bien, de manifiesto su saber hacer cine, su manera de encarar las distintas situaciones apoyándose en una sensibilidad que sabe encontrar, aún en las situaciones más simples, el resplandor que las transforma en algo especial. Esa forma particular de mirar la realidad tiene relación con la película que vamos a ver ahora, Los $\mathbf{4 0 0}$ golpes, cuya trama anecdótica tiene mucho de autobiográfica. Durante su infancia Truffaut pasó por situaciones difíciles, en algún momento, por problemas con la justicia, estuvo en un Instituto para menores, parte de ese transcurrir penoso aparece en el film que vamos a ver.

Para el adolescente rebelde y sensible que era entonces Truffaut, el encuentro con el crítico y teórico Andre Bazin fue la «piedra angular» sobre la que se asentó su futuro. Vivió incluso durante un tiempo en casa del matrimonio de André y Janine Bazin, esa relación hizo que Bazin se convirtiera en una especie de mentor, incluso de padre adoptivo de Truffaut. Después vendría el encuentro con otros jóvenes ci- néfilos, entre ellos Godard, Rivette, Chabrol, Rohmer. Todos ellos empezaron como críticos, por su parte Truffaut fue un crítico temible, gran polemista, y como es de suponer eso contribuyó a que se hiciera de muchos amigos y también de muchos enemigos. Volviendo al film de hoy, después de Les mistons mencionado recién, que había sido muy bien recibida por el público y la crítica, Truffaut se puso a trabajar en un proyecto de largometraje. En un primer momento se llamaba "La fuga de Antoine», y ya aparecía el personaje de Antoine Doinel, que se convertiría después en personaje central de varios de sus films, interpretado por Jean-Pierre Leaud.

El día en que se dió comienzo a la filmación de Los $\mathbf{4 0 0}$ golpes, murió André Bazin. A él será dedicado el film. Después del triunfo que obtuvo en Cannes, cuando el film comenzó a ser exhibido, empezaron también los conflictos con su familia, especialmente con su madre, a quien evidentemente le resultó muy molesto verse representada de la manera en que lo es, en la película. Le reprochaban además ventilar cuestiones íntimas. Con el tiempo esos conflictos empezarán a calmarse.

Hay en Los $\mathbf{4 0 0}$ golpes momentos duros, tristes, que Truffaut no suaviza, ni adorna, y hay otros momentos de plenitud, en los que la gracia de la infancia, de la adolescencia, con total libertad, se despliega.

El final es un momento de gran intensidad, que cierra admirablemente un film trabajado en cada una de sus secuencias con mirada atenta, por momentos implacable, siempre sensible. 